\title{
Reversal of Haloperidol-Induced Extrapyramidal Side Effects in Cebus Monkeys by 8-Hydroxy-2-(di-n-propylamino)tetralin and Its Enantiomers
}

\author{
Curt L. Christoffersen, B.A., and Leonard T. Meltzer, Ph.D.
}

( \pm )-8-Hydroxy-2-(di-n-propylamino)tetralin $(8-\mathrm{OH}-$ DPAT), (+)-8-OH-DPAT, and (-)-8-OH-DPAT produced dose-related reversals of haloperidol-induced extrapyramidal side effects (EPS) in cebus monkeys, with all compounds producing similar almost complete reversals at $0.1 \mathrm{mg} / \mathrm{kg}$ IM. These compounds were more potent than apomorphine, which reversed haloperidol-induced EPS at 0.3, but not $0.1, \mathrm{mg} / \mathrm{kg} I \mathrm{M}$. The data indicate that the reversal of haloperidol-induced EPS by ( \pm )-8-OH-DPAT and its enantiomers is mediated via effects at $5-H_{1 A}$ receptors, not dopamine $D_{2}$ receptors. Thus, inclusion of 5-HT $\mathrm{T}_{1 \mathrm{~A}}$ agonist activity in novel antipsychotics may reduce EPS liability. [Neuropsychopharmacology

18:399-402, 1998] (C) 1998 American College of Neuropsychopharmacology. Published by Elsevier Science Inc.
KEY WORDS: Extrapyramidal side effects; Serotonin- ${ }_{1 A}$; Haloperidol; Cebus monkeys; Dopamine antagonists; Dystonias

Alterations in serotonin (5-HT) neurotransmission has been hypothesized to modulate both the therapeutic and extrapyramidal side effect (EPS) liability of antipsychotic agents (Meltzer 1995). In studies in rats, the $5-\mathrm{HT}_{1 \mathrm{~A}}$ agonist (士)-8-hydroxy-2-(di-n-propylamino)tetralin (8-OHDPAT) potentiated the antiavoidance and reduced the cataleptic effects of the dopamine (DA) antagonist raclopride (Wadenberg and Ahlenius 1991). The reduction of haloperidol catalepsy by $( \pm)-8-\mathrm{OH}-\mathrm{DPAT}$ was postulated to be due to inhibition of 5-HT release by stimulation of somatodendritic 5- $\mathrm{HT}_{1 \mathrm{~A}}$ receptors on raphe neurons (Invernizzi et al. 1988). Thus, a functional reduction of 5-HT

From Parke-Davis Pharmaceutical Research, Division of WarnerLambert Co., Ann Arbor, Michigan.

Address correspondence to: L.T. Meltzer, Ph.D., Parke-Davis Pharmaceutical Research, Division of Warner-Lambert Co., 2800 Plymouth Road, Ann Arbor, MI 48105.

Received June 25, 1997; accepted September 15, 1997. neurotransmission has been suggested to underlie these effects. These data suggest that concurrent treatment with $5-\mathrm{HT}_{1 \mathrm{~A}}$ agonists, or the inclusion of $5-\mathrm{HT}_{1 \mathrm{~A}}$ activity in an antipsychotic agent, may improve the efficacy/side effect ratio of standard antipsychotic treatment.

Modulation of the dystonic effects of haloperidol has been used as a model for assessing ways to reduce EPS in humans. In the present studies, we evaluated the role of $5-\mathrm{HT}_{1 \mathrm{~A}}$ receptors in modulating EPS by assessing the ability of ( \pm )-8-OH-DPAT and its enantiomers to reverse haloperidol-induced EPS in cebus monkeys that had been sensitized to the dystonic effects of haloperidol. A goal of this study was to examine compounds with different degrees of intrinsic activity at $5-\mathrm{HT}_{1 \mathrm{~A}}$ receptors for their ability to reverse halperidol-induced EPS.

\section{MATERIALS AND METHODS}

Two adult female and one male cebus monkeys (Cebus apella; $2.0-4.0 \mathrm{~kg}$ ) were housed singly. Animals were maintained under a 12-h light-dark cycle with free ac- 
cess to standard chow and water. Animal care was in accordance with guidelines established by the National Institutes of Health and the American Association for the Accreditation of Laboratory Animal Care. All experimental protocols were approved by an Animal Care and Use Committee.

Cebus monkeys were sensitized to neurolepticinduced EPS by once weekly dosing with haloperidol (1 $\mathrm{mg} / \mathrm{kg}$ PO) for 8-12 weeks. Signs of EPS included: involuntary twisting of the neck or torso, protrusion of the tongue, tonic extension of the limbs and pressing of the body against cage walls. During the sensitization period, animals were rated weekly for the appearance of EPS. Once EPS appeared, the monkeys exhibited acute dystonias after administration of lower doses of haloperidol or in response to the administration of other DA antagonists that produce EPS in humans. A subjective rating scale was used to estimate the intensity of the EPS. Individual signs of EPS were rated as being absent (0), weak (1), or strong (2).

In sensitized cebus monkeys, haloperidol-induced EPS has an onset of approximately 1-2 $\mathrm{h}$ postinjection and has constant intensity from hours $2-6$, although the intensity at a fixed dose varies among monkeys. To conduct the present experiments, it was first necessary to screen monkeys to identify those that had stable EPS signs that were not disrupted by the injection procedure at $3 \mathrm{~h}$ posthaloperidol. It was observed that the handling necessary to administer an intramuscular injection would sometimes disrupt the EPS at the 15- and 30-min observation times. From a group of eight monkeys, three monkeys were identified that were suitable for testing.

To study the reversal of haloperidol-induced EPS, haloperidol, $0.5 \mathrm{mg} / \mathrm{kg} \mathrm{PO}$, was administered at time zero, and $3 \mathrm{~h}$ later monkeys were injected IM with vehicle or test drug. Observations were made at 1 -h intervals post-haloperidol and then at 15-min intervals for 1 $\mathrm{h}$ after administration of the reversal agent or saline. For graphic display of the time course of effect, at each time point, for each individual monkey, the scores for all signs present were totaled, and group means \pm SEM were derived. For data analysis, the cumulative EPS scores for the first hour postinjection were calculated and the haloperidol-vehicle group was compared with the haloperidol-treatment groups by one-way repeated measures analysis of variance with Bonferroni's method used to compare vehicle and individual drug treatments. Each time a different compound was tested, haloperidol-vehicle and the different haloperidol-drug conditions were run in a randomized order.

\section{Drugs}

( \pm )-8-OH-DPAT HBr, (+)-8-OH-DPAT $\mathrm{HBr}$ and (-)8-OH-DPAT $\mathrm{HBr}$ were purchased from Research Bio- chemicals International (Natick, MA). Haloperidol and apomorphine $\mathrm{HCl}$ were purchased from Sigma Chemicals (St. Louis, MO). Haloperidol was dissolved in lactic acid, the $\mathrm{pH}$ adjusted to 6.0 with $\mathrm{NaOH}$, and administered PO in water at $1 \mathrm{cc} / \mathrm{kg}$. Other compounds were dissolved in $0.9 \%$ saline and administered IM at $0.1 \mathrm{cc} / \mathrm{kg}$.

\section{RESULTS}

$( \pm)-8-\mathrm{OH}-\mathrm{DPAT},(+)-8-\mathrm{OH}-\mathrm{DPAT}$ and (-)-8-OH-DPAT produced dose-related reversals of haloperidol-induced, $0.5 \mathrm{mg} / \mathrm{kg}$ PO, EPS (Figure 1 and Table 1). A representative time course of the effect for (+)-8-OH-DPAT is shown in Figure 1. For all three compounds, $0.01 \mathrm{mg} /$ $\mathrm{kg}$ had no effect, whereas 0.03 and $0.1 \mathrm{mg} / \mathrm{kg}$ IM reversed the haloperidol-induced EPS. For all compounds, analysis of variance revealed a significant effect of treatment condition on the haloperidol-induced EPS $(( \pm)-8-\mathrm{OH}-\mathrm{DPAT}, \mathrm{F}=5.0, p<.05 ;(+)-8-\mathrm{OH}-$ DPAT, $\mathrm{F}=7.9, p<.05 ;(-)-8-\mathrm{OH}$-DPAT, $\mathrm{F}=5.3, p<$ .05). Bonferroni's method was used to delineate individual treatment differences versus haloperidol-vehicle (Table 1). As another way of examining the data, a

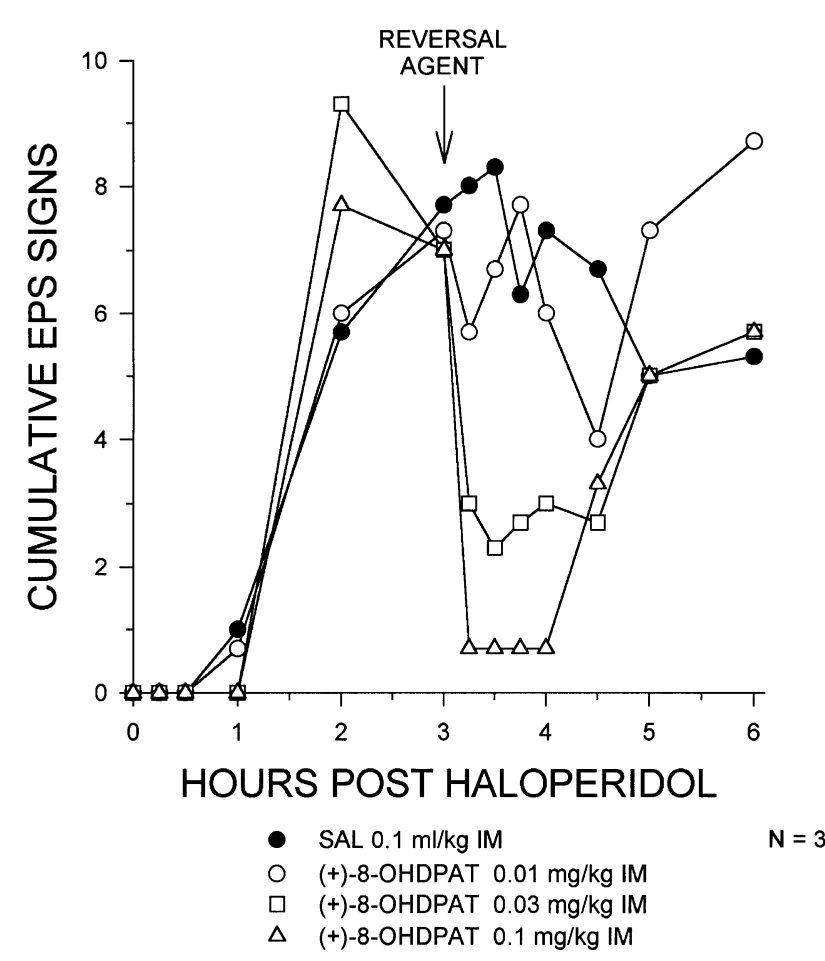

Figure 1. Reversal of haloperidol-induced EPS by (+)-8OH-DPAT. Haloperidol was administered at time zero. EPS signs were rated at individual time points and group means determined. Saline or (+)-8-OH-DPAT was administered IM at $3 \mathrm{~h}$ posthaloperidol. Data are the mean of three monkeys. SEM has been left out for clarity. 
Table 1. Apomorphine and ( \pm )-, (+)-, and (-)-8-OH-DPAT Reversal of HaloperidolInduced EPS in Cebus Monkeys

\begin{tabular}{|c|c|c|}
\hline \multirow[b]{2}{*}{ Treatment } & \multirow{2}{*}{$\begin{array}{c}\text { Cumulative EPS Score } \\
(\text { mean } \pm \text { SEM) }\end{array}$} & \multirow{2}{*}{$\begin{array}{c}\text { \# Animals } \\
\text { Reversed by }>50 \% \\
\text { \# Animals Tested }\end{array}$} \\
\hline & & \\
\hline $\mathrm{Hal}+\mathrm{Veh}$ & $30 \pm 6$ & \\
\hline $\mathrm{Hal}+$ Apo 0.1 & $30 \pm 5$ & $0 / 3$ \\
\hline $\mathrm{Hal}+$ Apo 0.3 & $9 \pm 6^{b}$ & $2 / 3$ \\
\hline $\mathrm{Hal}+\mathrm{Veh}$ & $26 \pm 3$ & \\
\hline $\mathrm{Hal}+( \pm)-8-\mathrm{OH}-\mathrm{DPAT} 0.01$ & $29 \pm 7$ & $0 / 3$ \\
\hline $\mathrm{Hal}+( \pm)-8-\mathrm{OH}-\mathrm{DPAT} 0.03$ & $17 \pm 5$ & $1 / 3$ \\
\hline $\mathrm{Hal}+( \pm)-8-\mathrm{OH}-\mathrm{DPAT} 0.1$ & $7 \pm 3$ & $3 / 3$ \\
\hline $\mathrm{Hal}+\mathrm{Veh}$ & $30 \pm 6$ & \\
\hline $\mathrm{Hal}+(+)-8-\mathrm{OH}-\mathrm{DPAT} 0.01$ & $26 \pm 8$ & $0 / 3$ \\
\hline $\mathrm{Hal}+(+)-8-\mathrm{OH}-\mathrm{DPAT} 0.03$ & $11 \pm 1$ & $2 / 3$ \\
\hline $\mathrm{Hal}+(+)-8-\mathrm{OH}-\mathrm{DPAT} 0.1$ & $3 \pm 1^{b}$ & $3 / 3$ \\
\hline $\mathrm{Hal}+\mathrm{Veh}$ & $24 \pm 6$ & \\
\hline $\mathrm{Hal}+(-)-8-\mathrm{OH}-\mathrm{DPAT} 0.01$ & $23 \pm 7$ & $0 / 3$ \\
\hline $\mathrm{Hal}+(-)-8-\mathrm{OH}-\mathrm{DPAT} 0.03$ & $16 \pm 4$ & $0 / 3$ \\
\hline $\mathrm{Hal}+(-)-8-\mathrm{OH}-\mathrm{DPAT} 0.1$ & $4 \pm 2^{b}$ & $3 / 3$ \\
\hline
\end{tabular}

$50 \%$ reduction in the cumulative EPS score for each animal for $1 \mathrm{~h}$ postinjection was chosen as a way of comparing the efficacy to reverse EPS. When compared by this method, $( \pm)-8-\mathrm{OH}-\mathrm{DPAT},(+)-8-\mathrm{OH}-\mathrm{DPAT}$ and $(-)-8-\mathrm{OH}-\mathrm{DPAT}$ all reversed the haloperidol-induced EPS by greater than $50 \%$ in all monkeys tested at 0.1 $\mathrm{mg} / \mathrm{kg}$, whereas there was a small distinction among the three compounds at $0.03 \mathrm{mg} / \mathrm{kg}$, with the $(+)-,( \pm)-$ and (-)- reversing 2 of 3,1 of 3 , and 0 of 3 monkeys, respectively. The EPS reversal produced by $( \pm)-,(+)-$ and (-)-8-OH-DPAT, $0.1 \mathrm{mg} / \mathrm{kg}$, was similar to that produced by apomorphine, $0.3 \mathrm{mg} / \mathrm{kg}$ (see below).

Administration of $( \pm)-,(+)$ - and (-)-8-OH-DPAT to haloperidol-sensitized monkeys was sometimes accompanied by tremors and prostration. However, the appearance of these signs was not correlated with the EPS reversal. In the monkeys used in the halperidol/8-OHDPAT interaction studies, $( \pm)-8-\mathrm{OH}-D P A T, 0.03 \mathrm{mg} / \mathrm{kg}$ IM alone, did not induce any EPS signs.

Tremors were observed in one and two monkeys at 0.1 and $0.3 \mathrm{mg} / \mathrm{kg} \mathrm{IM}$, respectively. No signs similar to those produced by DA agonists, such as apomorphine (see below) were observed.

Apomorphine reversed the haloperidol-induced EPS at 0.3 , but not $0.1 \mathrm{mg} / \mathrm{kg}$, IM (Table 1 ). The overall treatment effect was significant (ANOVA, $\mathrm{F}=9.2, p<$ $.05)$. In a separate group of haloperidol-sensitized cebus monkeys, apomorphine, $0.3 \mathrm{mg} / \mathrm{kg} \mathrm{IM}$, produced mild signs of stimulation, such as scratching and checking in four and three, respectively, out of six monkeys tested.

\section{DISCUSSION}

The present data demonstrate that $( \pm)-8-\mathrm{OH}-\mathrm{DPAT}$ and its enantiomers can reverse haloperidol-induced EPS in cebus monkeys. This reversal is postulated to occur by stimulation of $5-\mathrm{HT}_{1 \mathrm{~A}}$ receptors and not DA receptors and is based on the following observations and lines of reason: (1) \pm )-, (+)- and (-)-8-OH-DPAT have potent $5-\mathrm{HT}_{1 \mathrm{~A}}$ agonist effects and weak DA partial agonist effects; in binding assays $( \pm)-,(+)$ - and (-)-8-OHDPAT are over 100 -fold selective for $5-\mathrm{HT}_{1 \mathrm{~A}}$ versus $\mathrm{D}_{2}$ or $\mathrm{D}_{3}$ receptors and are over 1,000 -fold more potent at inhibiting serotoninergic dorsal raphe versus dopaminergic ventral tegmental neurons (Arvidsson et al. 1981; Ahlenius et al. 1989, 1990; Lejeune et al. 1997); (2) apomorphine is more potent and efficacious as a DA agonist compared with $( \pm)-,(+)-$ and $(-)-8-\mathrm{OH}-\mathrm{DPAT}$ (Skirboll et al. 1979; Meltzer et al. 1992; Lejeune et al. 1997); and (3) in the present experiments, $( \pm)-8-\mathrm{OH}-$ DPAT and its enantiomers were more potent than apomorphine in reversing haloperidol-induced EPS. In contrast, in a prior study in squirrel monkeys (Liebman et al. 1989), it was postulated the DA agonist properties of $( \pm)-8-\mathrm{OH}-\mathrm{DPAT}$ mediated the reversal of haloperidol-induced EPS; however, no comparison to apomorphine was conducted. Interaction studies with selective $5-\mathrm{HT}_{1 \mathrm{~A}}$ antagonists will be necessary to firmly conclude the role of $5-\mathrm{HT}_{1 \mathrm{~A}}$ receptors.

What $5-\mathrm{HT}_{1 \mathrm{~A}}$ intrinsic activity is necessary to reverse haloperidol-induced EPS? Although $( \pm)-,(+)$ - and $(-)-$ 8 -OH-DPAT are equipotent in receptor binding studies 
(Cornfield et al. 1991; Lejeune et al. 1997), in in vitro tests that reflect intrinsic activity at $5-\mathrm{HT}_{1 \mathrm{~A}}$ receptors, relative to 5-HT, ( \pm -8-OH-DPAT, and (+)-8-OH-DPAT have approximately $90-100 \%$ intrinsic activity whereas (-)-8OH-DPAT has approximately $50-60 \%$ intrinsic activity (Cornfield et al. 1991; Fowler et al. 1992; Lejeune et al. 1997). In addition, ( \pm )-8-OH-DPAT and (+)-8-OHDPAT appear to be twice as potent as (-)-8-OH-DPAT in these functional studies. A similar functional relationship is observed in in vivo tests that reflect efficacy at $5-\mathrm{HT}_{1 \mathrm{~A}}$ receptors, e.g., inhibition of 5-HTP synthesis, inhibition of raphe neuronal activity and induction of the 5- $\mathrm{HT}_{1 \mathrm{~A}}$ behavioral syndrome (Arvidsson et al. 1981; Lejeune et al. 1997). Based on the number of animals that showed a greater than $50 \%$ reduction in the haloperidol-induced EPS, the rank order of potency is $(+)->$ $( \pm)->(-)-8-\mathrm{OH}-\mathrm{DPAT}$, in agreement with the intrinsic activity at $5-\mathrm{HT}_{1 \mathrm{~A}}$ receptors. However, the small sample size and the steepness of the dose-response curve mitigates against making firm conclusions. In contrast, buspirone, which has DA antagonist activity and is a partial $5-\mathrm{HT}_{1 \mathrm{~A}}$ agonist with weaker intrinsic activity than (-)-8OH-DPAT (Hjorth and Carlsson 1982; McMillen et al. 1983; Fowler et al. 1992), produced EPS in haloperidolsensitized cebus and squirrel monkeys (Downs et al. 1985; Liebman et al. 1989; Christoffersen and Meltzer, unpublished observations). These data suggest that an intrinsic activity of at least $50 \%$ is necessary to reverse haloperidol-induced EPS. It is unclear from the data if 5$\mathrm{HT}_{1 \mathrm{~A}}$ autoreceptors or postsynaptic receptors mediate the reversal of the haloperidol-induced EPS.

In prior studies in the rat, the ( \pm )-8-OH-DPATinduced reversal of raclopride catalepsy was accompanied by impairment of treadmill performance, suggesting nonspecific effects on muscle tone and/or motor coordination (Wadenberg and Ahlenius 1991). However, the present observations that $( \pm)-8-\mathrm{OH}-\mathrm{DPAT}$ reversed the haloperidol-induced EPS without inducing adverse effects alone suggests that the EPS reversal is not due to nonspecific effects.

The present conclusions support the hypothesis that the combination of $5-\mathrm{HT}_{1 \mathrm{~A}}$ agonist activity and $\mathrm{D}_{2}$ antagonist activity may yield an antipsychotic agent with an improved profile of efficacy to EPS. An intrinsic activity that is at least similar to that of (-)-8-OH-DPAT may be required to reduce EPS liability. It will be necessary to study a complete dose range, in both efficacy and EPS tests to determine if $5-\mathrm{HT}_{1 \mathrm{~A}}$ activity reduces EPS liability relative to DA antagonists such as haloperidol.

\section{REFERENCES}

Ahlenius S, Hillegaart V, Wijkstrom A (1989): Evidence for selective inhibition of limbic forebrain dopamine syn- thesis by $8-\mathrm{OH}-\mathrm{DPAT}$ in the rat. Naunyn-Schmiedeberg's Arch Pharmacol 339:551-556

Ahlenius S, Hillegaart V, Wijkstrom A (1990): Increased dopamine turnover in the ventral striatum by $8-\mathrm{OH}-\mathrm{DPAT}$ administration in the rat. J Pharm Pharmacol 42:285-288

Arvidsson LE, Hacksell U, Nilsson JLG, Hjorth S, Carlsson A, Lindberg P, Sanchez D, Wikstrom H (1981): 8-Hydroxy2-(alkylamino)tetralin, new centrally acting 5-hydroxytryptamine receptor agonist. J Med Chem 24:921-923

Cornfield LJ, Lambert G, Arvidsson L-E, Mellin C, Vallgarda J, Hacksell U, Nelson DL (1991): Intrinsic activity of enantiomers of 8-hydroxy-2-(di-n-propylamino)tetralin and its analogs at 5-hydroxytryptamine 1A receptors that are negatively coupled to adenylate cyclase. Mol Pharmacol 39:780-787

Downs DA, Harrigan SE, Heffner TG (1985): Buspirone effects in a primate model of extrapyramidal dysfunction. Soc Neurosci Abstr 11:426

Fowler CJ, Ahlgren PC, Brannstrom G (1992): GH4ZD10 cells expressing rat $5-\mathrm{HT}_{1 \mathrm{~A}}$ receptors coupled to adenylyl cyclase are a model for the postsynaptic receptors in the rat hippocampus. Br J Pharmacol 107:141-145

Hjorth S, Carlsson A (1982): Buspirone: Effects on central monoaminergic transmission-possible relevance to animal experimental and clinical findings. Eur J Pharmacol 83:299-303

Invernizzi RW, Cervo L, Samanin R (1988): 8-Hydroxy-2-(di$\mathrm{n}$-propylamino)tetralin, a selective serotonin ${ }_{1 \mathrm{~A}}$ receptor agonist, blocks haloperidol-induced catalepsy by an action on raphe nuclei medianus and dorsalis. Neuropharmacology 27:515-518

Lejeune F, Newman-Tancredi A, Audinot V, Millan MJ (1997): Interactions of (+)- and (-)-8- and 7-hydroxy-2(di-n-propylamino)tetralin at human $(\mathrm{h}) \mathrm{D}_{3}, \mathrm{hD}_{2}$, and $\mathrm{h}$ serotonin $_{1 \mathrm{~A}}$ receptors and their modulation of the activity of serotoninergic and dopaminergic neurones in rats. J Pharmacol Exp Ther 280:1241-1249

Liebman JM, Gerhardt SC, Gerber R (1989): Effects of 5- $\mathrm{HT}_{1 \mathrm{~A}}$ agonists and $5-\mathrm{HT}_{2}$ antagonists on haloperidol-induced dyskinesias in squirrel monkeys: No evidence for reciprocal 5-HT-dopamine interaction. Psychopharmacology 97:456-461

McMillen BA, Metthews RT, Sanghera MK, Shepard PD, German DC (1983): Dopamine receptor antagonism by the novel anti-anxiety drug, buspirone. J Neurosci 3:733-738

Meltzer HY (1995): Role of serotonin in the action of atypical antipsychotic drugs. Clin Neurosci 3:64-75

Meltzer LT, Christoffersen CL, Serpa KA, Pugsley TA, Razmpour A, Heffner TG (1992): Lack of involvement of haloperidol-sensitive sigma binding sites in modulation of dopamine neuronal activity and induction of dystonias by antipsychotic drugs. Neuropharmacology 9:961-967

Skirboll LR, Grace AA, Bunney BS (1979): Dopamine autoand postsynaptic receptors: Electrophysiological evidence for differential sensitivity to dopamine agonists. Science 206:80-82

Wadenberg ML, Ahlenius S (1991): Antipsychotic-like profile of combined treatment with raclopride and 8-OH-DPAT in the rat: Enhancement of antipsychotic-like effects without catalepsy. J Neural Trans [GenSect] 83:43-53 